\title{
Застосування короткострокового стандартизованого режиму з ін'єкційним препаратом для лікування випадків Риф-ТБ: чому Україна не Бангладеш
}

\author{
Дудник А.Б. ${ }^{1}$, Мацера В.Л. ${ }^{2}$, Нікітченко Т.В. ${ }^{2}$, Бехарська В.А. ${ }^{2}$
}

1. Вінницький національний медичний університет ім. М.І. Пирогова, м. Вінниця, Україна

2. Вінницьке обласне спеціалізоване територіальне медичне об'єднання «Фтизіатрія», м. Вінниця, Україна

Обґрунтування. Стрімке зменшення внаслідок пандемії COVID-19 кількості виявлених випадків туберкульозу (ТБ) з 25237 у 2019 р. до 17593 у 2020 р., тобто на 29,8 \% (Центр громадського здоров'я, 2021), створює ілюзію подолання проблеми. Водночас широке застосування імуносупресивних лікарських засобів (дексаметазон, тоцилізумаб) для лікування COVID-19-асоційованих пневмоній серед населення з поширеною латентною туберкульозною інфекцією (Cohen A. et al. Eur. Respir. J. 2019) може стати рушійним фактором зростання захворюваності на ТБ у майбутньому.

Ведення випадків стійкого до рифампіцину ТБ (Риф-ТБ) на підставі виявлення мутацій у ділянці гена гроВ за допомогою картриджів Xpert ${ }^{\oplus}$ MTB/RIF та Xpert MTB/RIF Ultra залишається складним завданням для лікарів. Через обмежену можливість швидкої діагностики стійкості до інших протитуберкульозних лікарських засобів і відсутність регіональних даних щодо поширеності мутацій початкова схема часто $\epsilon$ неефективною. У 2019 р. Всесвітня організація охорони здоров'я (ВОО3) опублікувала «Консолідовану настанову щодо ведення випадків медикаментозно-стійкого ТБ», що базувалася на метааналізі досліджень, які вивчали ефективність і безпечність застосування протитуберкульозних препаратів (Ahmad et al. Lancet. 2018; Trebucq A. et al. Int. J. Tuberc. Lung Dis. 2018).

Мета. Вивчення практичних аспектів застосування стандартизованої короткострокової схеми лікування з ін'єкційним препаратом 4-6 Km(Am)-Mfx-Pto(Eto)-Cfz-Z-Hhighdose-E/5 Mfx-Cfz-Z-E в пацієнтів із Риф-ТБ.
Матеріали та методи. У рамках дослідження було ретроспективно проаналізовано випадки лікування Риф-ТБ за 2019 р. у Вінницькій області з використанням стандартизованої короткострокової схеми лікування з ін'єкційним препаратом.

Результати. У 2019 р. лише 35 із 156 (22 \%) випадків Риф-ТБ у Вінницькій області відповідали критеріям призначення короткострокової схеми лікування. Основними критеріями виключення були дисемінована форма ТБ, прийом препаратів другого ряду, що використовуються в схемі понад 1 місяць, позалегенева локалізація. Усі пацієнти розпочали короткострокову схему в період очікування результатів фенотипічного тесту медикаментозної чутливості. Через виявлення додаткової резистентності 22 із 35 пацієнтів (63\%) були переведені на довгострокову індивідуалізовану схему, ще 5 із 35 (14\%) були виключені через розвиток побічних реакцій. Отже, лише 8 із 35 осіб (23\%) завершили короткострокове лікування за початковою схемою, тобто лише 5 \% (8/156) із когорти пацієнтів із Риф-ТБ. Викликає занепокоєння призначення 5 препаратів групи С в інтенсивну фазу, що суперечить пріоритетності включення ефективніших препаратів із груп А та В і втричі збільшує кількість пігулок для перорального прийому (з 3-5 до 14-16).

Висновки. Призначення короткострокового стандартизованого режиму з ін'єкційним препаратом без виконання лінійного зонд-аналізу може бути рекомендоване лише 5 \% хворих на Риф-ТБ в Україні. 